\title{
Effect of plaque accumulation and salivary factors on enamel demineralization and plaque composition in situ
}

\section{Efeito do acúmulo de placa e de fatores salivares na desmineralização do esmalte e composição da placa dental in situ}

Livia Maria Andaló Tenuta*

José Eduardo de Oliveira Lima**

Celso Luiz Cardoso***

Cinthia Pereira Machado Tabchoury****

Jaime Aparecido Cury****

\begin{abstract}
This study evaluated the effect of some plaque and salivary factors on caries progression in situ. The salivary secretion rate, buffering capacity and mutans streptococci counts from 13 volunteers were determined. For three distinct periods of time, 4, 7 and 10 days, each of them wore a palatal appliance containing 4 bovine enamel blocks. They used a non-fluoridated dentifrice during the experiment and a $20 \%$ sucrose solution was dripped onto the blocks 10 times a day. Mutans streptococci (MS), calcium (Ca), and insoluble polysaccharide (IP) were quantified in the dental plaque formed on the enamel blocks, after each period. Enamel demineralization was assessed by surface microhardness, and the percentage of surface microhardness change (\%SMC) in relation to the baseline values was calculated. Enamel demineralization occurred after each period of plaque accumulation $(p<0.05)$, and the \%SMC increased with time (from 13.8 to $48.3 \%$ ). The concentrations of $\mathrm{Ca}$ and IP in plaque were not statistically different among the experimental times, but significant correlations were found between these concentrations and \%SMC. Neither the salivary factors assessed initially nor mutans streptococci in plaque presented statistically significant correlations to \%SMC. The results suggest that enamel demineralization is time-dependent and is more related to the composition of the biofilm formed than to the salivary factors studied.
\end{abstract}

DESCRIPTORS: Dental plaque; Tooth demineralization; Dental enamel; Streptococcus mutans; Saliva.

RESUMO: Este estudo foi realizado para avaliar o efeito de alguns fatores salivares e da composição da placa dental na progressão da cárie in situ. O fluxo salivar, a capacidade tampão e os níveis de estreptococos mutans na saliva de 13 voluntários foram determinados inicialmente. Durante 3 períodos distintos de 4,7 e 10 dias, eles utilizaram um dispositivo palatino contendo 4 blocos de esmalte bovino. Dez vezes ao dia, uma solução de sacarose a $20 \%$ foi gotejada sobre os blocos de esmalte. Durante o experimento, os voluntários utilizaram um dentifrício não fluoretado. Estreptococos mutans (EM), cálcio (Ca) e polissacarídeos insolúveis (PI) foram quantificados na placa formada sobre os blocos após cada período. A desmineralização do esmalte foi avaliada através de microdureza de superfície, e a porcentagem de perda de dureza de superficie (\%PDS) foi calculada em relação aos valores de dureza iniciais. Houve desmineralização do esmalte após cada período de acúmulo de placa $(\mathrm{p}<0,05)$ e a \%PDS aumentou com o tempo (de 13,8 para $48,3 \%)$. As concentrações de Ca e PI na placa dental não foram diferentes entre os tempos experimentais, mas correlacões significantes foram encontradas entre elas e a \%PDS. Os fatores salivares avaliados inicialmente e os níveis de estreptococos mutans na placa não apresentaram correlação estatisticamente significante com a \%PDS. Os resultados mostraram que a desmineralização do esmalte depende do tempo e está mais relacionada à composição do biofilme formado do que aos fatores salivares estudados.

DESCRITORES: Placa dentária; Desmineralização do dente; Esmalte dentário; Streptococcus mutans; Saliva.

\section{INTRODUCTION}

Dental plaque left undisturbed over teeth is implicated in dental caries development, and, in the presence of frequent exposure to sucrose, white spots are clinically detected after 14-21 days ${ }^{7,22}$. Using sensitive laboratory methods to assess enamel demineralization it was demonstrated that even shorter periods were enough to cause enamel alterations ${ }^{2,16}$. However, the relationship between

\footnotetext{
${ }^{*}$ PhD Student, Area of Cariology; ***Assistant Professor of Biochemistry; **** Professor of Biochemistry - School of Dentistry of Piracicaba, State University of Campinas.

**Assistant Professor of Pedodontics, School of Dentistry of Bauru, University of São Paulo.

*** Professor of Microbiology, Department of Clinical Analysis, State University of Maringá.
} 
Tenuta LMA, Lima JEO, Cardoso CL, Tabchoury CPM, Cury JA. Effect of plaque accumulation and salivary factors on enamel demineralization and plaque composition in situ. Pesqui Odontol Bras 2003;17(4):326-31.

salivary factors, period of dental plaque accumulation, and dental caries deserves further research.

It has been assumed that plaque cariogenicity is influenced by a dynamic interaction of dietary and salivary, microbiological and biochemical factors. Salivary flow rate, buffer capacity and mutans streptococci counts were significantly related to caries occurrence in some studies ${ }^{9,19}$, and the evaluation of these factors has been proposed as a tool for caries risk assessment; but the associations with caries are normally weak. Also, mutans streptococci counts in plaque are considered to be indicative of caries activity ${ }^{10}$, although an inconsistent relationship between numbers of mutans streptococci in plaque and caries state of enamel beneath it has been found in some studies ${ }^{21}$.

Considering the biochemical factors involved in dental caries development, it is suggested that a shift in demineralization is related to higher concentrations of insoluble polysaccharides and lower concentrations of inorganic minerals in dental plaque p., $^{1,5,11,15}$.

Although the effect of salivary and microbiological factors on dental caries has been studied, there are not data about the role of those factors in the formation and maturation of a cariogenic dental plaque and on enamel demineralization after short periods of plaque accumulation. Thus, the purpose of this experimental study was two-fold: (1) to evaluate the progression of in situ enamel demineralization over time, under a highly cariogenic situation, and (2) to investigate the influence of some plaque and salivary factors on such demineralization.

\section{MATERIALS AND METHODS Experimental design}

The study involved a crossover design performed in three distinct phases, at 4, 7 and 10 days of plaque accumulation in situ. Ethical approval was obtained from the Ethics Committee, School of Dentistry of Bauru. Thirteen healthy volunteers, 19-28 years old, were selected among dental students at the State University of Maringá, Paraná, Brazil. None of the selected volunteers had been recently treated with antibiotics. Before the experimental period, unstimulated and stimulated saliva was collected and the salivary flow rate was determined. Stimulated-saliva buffer capacity and salivary mutans streptococci counts were also investigated.
Enamel blocks ( $4 \times 4 \times 2 \mathrm{~mm}$ ) were prepared from bovine incisors and stored in a $2 \%$ formaldehyde solution (Vetec Química Fina Ltda., Rio de Janeiro, Brazil), pH 7.0, for at least a month ${ }^{4,5}$. The enamel surface was polished for baseline surface microhardness (SMH) determination. The volunteers wore acrylic palatal appliances containing four dental enamel blocks during distinct periods of time, 4, 7 and 10 days. For each period, a new set of enamel blocks was used. Enamel blocks were placed in a recess $1.0 \mathrm{~mm}$ below the acrylic flange, and plaque was allowed to accumulate over them, protected from any mechanical disturbance by a plastic mesh fixed onto the acrylic surface ${ }^{4,5}$. Ten times a day the appliances were removed from the mouth and one drop of a $20 \%$ sucrose solution (Labsynth, Diadema, SP, Brazil) ${ }^{4,5}$ was dripped over each enamel block. After 5 minutes the appliances were reinserted in the mouth. The volunteers received instructions to wear the appliance at all times, including at night, but to remove it during meals or while consuming beverages. They used a non-fluoridated dentifrice 10 days before and during the study, but drank fluoridated water (about $0.7 \mathrm{ppm}$ ). The test subjects received oral and written instructions to refrain from using any antibacterial or fluoridated product.

The volunteers were randomly assigned to begin the in situ phase at the different periods $(4,7$ or 10 days). A washout period of 7 days was allowed between each phase. After each demineralization period, the dental plaque formed on the enamel blocks was pooled for microbiological and biochemical analysis. Enamel SMH was determined again, and the percentage of surface microhardness change (\%SMC) was calculated.

\section{Salivary flow rate and buffer capacity}

For the unstimulated collection, volunteers were seated with their heads slightly down, and gently spat the saliva accumulated in their mouth into the receiving beaker. For the stimulated flow rate determination, volunteers chewed a $1 \mathrm{~cm}$ piece of a sterilized latex tube (Auriflex, São Roque, $\mathrm{SP}$, Brazil) for 5 minutes. The flow rates were expressed in $\mathrm{ml} / \mathrm{min}$. For the buffer capacity determination, triplicates of $1 \mathrm{ml}$ of stimulated saliva were transferred to tubes containing $3 \mathrm{ml}$ of tritated 5 mM HCl (Merck, Darmstadt, Germany). The tubes were closed and inverted 5 times, opened and left to stand for 5 minutes. Final pH of 
Tenuta LMA, Lima JEO, Cardoso CL, Tabchoury CPM, Cury JA. Effect of plaque accumulation and salivary factors on enamel demineralization and plaque composition in situ. Pesqui Odontol Bras 2003;17(4):326-31.

the mixture was determined using a $\mathrm{pH}$-meter $( \pm 0.01)$, calibrated with the standards $\mathrm{pH} 7.0$ and 4.0 .

\section{Mutans streptococci counts in saliva}

Stimulated saliva was homogenized in a Thermolyne mixer (Barnsted International, Dubuque, IA, USA) for $30 \mathrm{~s}$ and ten-fold serial dilutions in saline were plated in duplicate on a petri dish (Inlab, Diadema, SP, Brazil) containing mitis-salivariusbacitracin (MSB) agar (Difco Laboratories, Detroit, MI, USA) ${ }^{8}$, by the drop-counting technique ${ }^{13}$. The plates were incubated in microaerophilic condition (candle jar) at $37^{\circ} \mathrm{C}$ for $48 \mathrm{~h}$. Only colonies with typical morphology were counted. The detection limit with the methods used was $50 \mathrm{CFU} / \mathrm{ml}$ of saliva. The number of $\mathrm{CFU} / \mathrm{ml}$ of saliva was calculated and converted to $\log _{10}$ for the statistical analysis.

\section{Mutans streptococci counts in dental plaque}

Plaque collection was always done at the end of the morning or afternoon, without controlling the time after the last sucrose exposure. At the end of each experimental period, plaque samples collected from two opposite blocks were immediately transferred to screw-capped vials containing $2 \mathrm{ml}$ of a sterile $0.15 \mathrm{M}$ phosphate-buffered saline solution, $\mathrm{pH} \mathrm{7.4}$, and 15-20 glass beads $(1 \mathrm{~mm}$ in diameter). The plaque was dispersed using a Thermolyne mixer for $30 \mathrm{~s}$ and ten-fold serial dilutions in sterile buffered saline were cultivated on MSB agar and counted as described for saliva. Different colony morphologies were identified by Gram staining and morphology.

Mutans streptococci in dental plaque was estimated as the percentage of total bacteria, cultivated on brucella agar (Difco Laboratories, Detroit, MI, USA) supplemented with hemin, vitamin K and $5 \%$ sterile defibrinated sheep blood, incubated at $37^{\circ} \mathrm{C}$ for $72-96 \mathrm{~h}$, in a Gaspak anaerobic jar (BD Diagnostic Systems, Sparks, MD, USA). The detection limit with the methods used was $50 \mathrm{CFU} / \mathrm{ml}$ of plaque suspension.

\section{Biochemical analysis of dental plaque}

Plaque samples from another two opposite enamel blocks were pooled, as described above, and dried for $24 \mathrm{~h}$ in vacuum over $\mathrm{P}_{2} \mathrm{O}_{5}$. The dry weight was then obtained $( \pm 0.01 \mathrm{mg})$. Analysis of acid soluble $\mathrm{Ca}$ and insoluble polysaccharides (IP) in dental plaque was performed according to Cury et $a .^{4,5}(1997,2000)$. Acid and alkali treatments were performed using $0.1 \mathrm{ml}$ of $0.5 \mathrm{M} \mathrm{HCl}$ and $0.2 \mathrm{ml}$ of $1.0 \mathrm{~N} \mathrm{NaOH}$ (Vetec Química Fina Ltda., Rio de Janeiro, Brazil) per mg of plaque, respectively. For samples with less than $1.0 \mathrm{mg}$ of dry weight, $0.1 \mathrm{ml}$ of $0.5 \mathrm{M} \mathrm{HCl}$ and $0.2 \mathrm{ml}$ of $1.0 \mathrm{~N} \mathrm{NaOH}$ were used.

\section{Microhardness analysis}

$\mathrm{SMH}$ was measured using a Knoop indenter with a $50 \mathrm{~g}$ load for $5 \mathrm{~s}$ and a Future-Tech FM microhardness tester coupled to the FM-ARS software (version 2.00.01) (Future-Tech Corp., Tokyo, Japan). After each phase, SMH was evaluated by making one row of five indentations spaced at $100 \mu \mathrm{m}$ on the side of the five baseline measurements, and the percentage of surface microhardness change (\%SMC) was calculated $(\% \mathrm{SMC}=$ $\mathrm{SMH}$ after demineralization - baseline $\times 100 /$ baseline).

\section{Statistical analysis}

Data on \%SMC, Ca, IP, and \% of mutans streptococci in plaque were transformed to fit the statistical tests properly. Paired- $t$ test was used to compare baseline and final $\mathrm{SMH}$ in the three periods of plaque accumulation. The correlation between salivary flow rate, buffer capacity, mutans streptococci counts in saliva and inorganic concentration in plaque and the \%SMC was investigated by Pearson's correlation test. Differences among the three experimental periods in relation to \%SMC and the inorganic concentration in dental plaque were tested by two-way ANOVA followed by Tukey's test. Friedman's test was used when the same comparison was made for mutans streptococci in dental plaque. The correlation between the percentage of these bacteria in plaque and enamel demineralization was assessed using Spearman's coefficient test. The tests were performed using the SAS System (version 8.02, SAS Institute Inc., Cary, NC, 1999) and the level of significance was set at $\mathrm{p}<0.05$.

\section{RESULTS}

The volunteers' unstimulated salivary flow rate ranged from 0.10 to $1.26 \mathrm{ml} / \mathrm{min}$ (mean $0.41 \mathrm{ml} / \mathrm{min}$ ), and stimulated salivary flow rate from 0.74 to $2.80 \mathrm{ml} / \mathrm{min}$ (mean $1.54 \mathrm{ml} / \mathrm{min}$ ). The buffer capacity varied between 3.46 and 6.42 
Tenuta LMA, Lima JEO, Cardoso CL, Tabchoury CPM, Cury JA. Effect of plaque accumulation and salivary factors on enamel demineralization and plaque composition in situ. Pesqui Odontol Bras 2003;17(4):326-31.

TABLE 1 - Surface microhardness analysis of enamel blocks according to the periods of plaque accumulation $($ mean $\pm \mathrm{SE} ; \mathrm{n}=13)$.

\begin{tabular}{c|c|c|c}
\hline \hline \multirow{2}{*}{ Time (days) } & \multicolumn{2}{|c|}{ SMH } & \multirow{2}{*}{$\%$ SMC } \\
\cline { 2 - 4 } & Baseline & $\begin{array}{c}\text { After in situ } \\
\text { demineralization }\end{array}$ & $-13.8 \pm 18.1^{\mathrm{a}}$ \\
\hline 4 & $340.7 \pm 2.4^{\mathrm{A}}$ & $294.0 \pm 61.8^{\mathrm{B}}$ & $-19.3 \pm 25.1^{\mathrm{a}}$ \\
\hline 7 & $340.9 \pm 5.0^{\mathrm{A}}$ & $275.1 \pm 87.2^{\mathrm{B}}$ & $-48.3 \pm 26.4^{\mathrm{b}}$ \\
\hline \hline
\end{tabular}

Means followed by different letters are statistically significant $(\mathrm{p}<0.05)$. Capital letters show the difference between baseline and after cariogenic challenge SMH for each group; lower case letters show differences between the periods of plaque accumulation. $\mathrm{SMH}=$ surface microhardness; $\mathrm{SMC}=$ surface microhardness change.

TABLE 2 - Coefficient tests comparing \%SMC, \%mutans streptococci, Ca and IP concentrations in plaque.

\begin{tabular}{l|c|c}
\hline \multicolumn{1}{c|}{ Correlation } & $\mathrm{r}$ & $\mathrm{p}$ value \\
\hline \%SMC versus \%mutans streptococci & 0.11 & 0.500 \\
\hline \%SMC versus Ca & -0.39 & $0.017^{*}$ \\
\hline \%SMC versus IP & 0.44 & $0.005^{*}$ \\
\hline \hline
\end{tabular}

$\mathrm{r}$ = Pearson's correlation coefficient; SMC = surface microhardness change; Ca = calcium; IP = insoluble polysaccharides *Statistically significant $(\mathrm{p}<0.05)$

(mean 4.98). The lowest number of mutans streptococci was $500 \mathrm{CFU} / \mathrm{ml}$ of saliva, and the highest was $230,000 \mathrm{CFU} / \mathrm{ml}$ of saliva.

Table 1 shows that a significant reduction in enamel surface microhardness occurred after each demineralization period. The highest \%SMC was observed after 10 days of cariogenic challenge, but the difference between the 4 and 7 days groups was not statistically significant (Table 1).

The correlation between the baseline microbiological and salivary factors and the mean \%SMC for each volunteer was not statistically significant $(\mathrm{p}>0.05)$.

Mutans streptococci were not detected in 17 of the 39 samples of plaque analyzed. When present, the proportion of these bacteria in total viable count was low (between $0.008 \%$ and $0.472 \%$ ), and no trend among groups or volunteers could be observed. Indeed, no significant correlation was found between the proportion of mutans streptococci in plaque and the \%SMC (Table 2).

Ca concentration in plaque decreased from 2.14 to $1.77 \mu \mathrm{g} / \mathrm{mg}$ and IP increased from 131.8 to $148.8 \mu \mathrm{g} / \mathrm{mg}$ with longer times of plaque accumulation, but no statistically significant difference was found between the three groups. On the other hand, $\mathrm{Ca}$ and IP concentrations in the biofilm presented a significant positive and negative associa- tion, respectively, to the enamel demineralization during the three periods (Table 2).

\section{DISCUSSION}

It is well known that dental plaque accumulated over teeth, without mechanical disturbance and supplemented with fermentable sugars, certainly leads to dental enamel demineralization ${ }^{16,22}$. However, there are not data about the factors that might influence the formation of the cariogenic biofilm and that could explain the different demineralization patterns found among different subjects.

In the present study, enamel demineralization was observed after 4 days of dental plaque accumulation at high frequency exposure to sugar (Table 1). This could have occurred in less time, but the pilot study (data not shown) revealed that after $48 \mathrm{~h}$, no change in enamel surface microhardness (SMH) could be observed. As SMH is considered a very sensitive method of evaluating early caries lesion $^{23}$, we can suggest that it takes around 3-4 days for dental plaque to manifest its cariogenicity. This period could be shorter for bovine enamel ${ }^{6}$, but the findings in this study are similar to those for human enamel ${ }^{2}$. Demineralization increased with time and was visible as white spots after a 10-day high cariogenic challenge period. 
Tenuta LMA, Lima JEO, Cardoso CL, Tabchoury CPM, Cury JA. Effect of plaque accumulation and salivary factors on enamel demineralization and plaque composition in situ. Pesqui Odontol Bras 2003;17(4):326-31.

Nevertheless, we did not find any relationship between the biochemical salivary factors assessed at baseline and the subsequent enamel demineralization observed. These findings are in agreement with those of some authors ${ }^{9}$ but differ from the results of others ${ }^{19}$. Our data support the report that the association between these factors and caries activity is weak, suggesting their use in a longitudinal and regular follow-up of a patient ${ }^{18}$, rather than as caries predictors. A possible explanation for the lack of association between salivary flow rate and buffer capacity, and enamel demineralization is that the experimental model used simulates an interproximal plaque, where the access to saliva is limited ${ }^{23}$. Also, none of the volunteers presented a low salivary flow rate, which may also have contributed to the lack of relationship.

Considering mutans streptococci levels in saliva, its correlation to the subsequent enamel demineralization was also not statistically significant. Other authors also found limited results when assessing the usefulness of these bacteria counts as a tool for predicting individual caries development ${ }^{17}$. Thus, it is reasonable to consider that such tests must be carefully used when predicting caries risk on an individual basis. However, the low levels of mutans streptococci found in the saliva of the volunteers may have contributed to the lack of relationship found in this study. Using populations with wide-ranging levels of mutans streptococci in saliva, some studies were able to find a relationship between them and present or future dental caries experience ${ }^{9,19}$.

In addition, the present study also did not find a relationship between enamel demineralization and the proportion of mutans streptococci in the plaque formed (Table 2). This finding is in agreement with those of longitudinal ${ }^{12}$, cross-sectional $^{17,21}$, and in situ studies ${ }^{3,14}$, but in contrast to those of other publications ${ }^{10}$. This can be explained by the fact that the period of plaque accumulation

\section{REFERENCES}

1. Ashley FP. Calcium and phosphorus concentrations of dental plaque related to dental caries in 11- to 14-year-old male subjects. Caries Res 1975;9:351-62.

2. Boyar RM, Thylstrup A, Holmen L, Bowden GH. The microflora associated with the development of initial decalcification below orthodontic bands in vivo in children living in a fluoridated-water area. J Dent Res 1989; 68:1734-8

3. Cury JA, Francisco SB, Del Bel Cury AA, Tabchoury CPM. In situ study of sucrose exposure, mutans streptococci in was not enough for these bacteria to emerge in high concentrations in plaque ${ }^{14}$.

With regard to the chemical composition of dental plaque, the concentration of IP was the same at all periods, but was significantly related to enamel demineralization (Table 2). This result demonstrates the cariogenic potential of a biofilm enriched with extracellular polysaccharides ${ }^{20}$, which has been shown in situ $u^{4,5}$ and in vivo ${ }^{15}$. The low mutans streptococci counts in plaque found in this study support the idea that polysaccharide production may be more important than the number of these bacteria, as suggested by MattosGraner et al. ${ }^{11}$.

The significant relationship found between $\mathrm{Ca}$ levels in plaque and loss of enamel SMH is in agreement with the findings of Cury et $a l^{4,5}$, and shows the importance of this ion in caries development ${ }^{1}$.

\section{CONCLUSIONS}

In summary, it was shown that the time for dental plaque to cause enamel demineralization can be as short as four days. As none of the salivary factors studied could be closely implicated in cariogenicity, the results suggest that the change induced by sugar in the biofilm formed is the most relevant factor involved in caries development.

\section{ACKNOWLEDGEMENTS}

The authors wish to thank the volunteers for their valuable participation in this study and FAPESP (Fundação de Amparo à Pesquisa do Estado de São Paulo, grant no. 98/16471-0) for the scholarship during the graduate course of the first author at the School of Dentistry of Bauru, University of São Paulo. This work was based on a thesis submitted by the first author to the School of Dentistry of Bauru, as partial fulfillment of the requirements of the Master's Program in Pedodontics.

dental plaque and dental caries. Braz Dent J 2001; 12:101-4.

4. Cury JA, Rebelo MAB, Del Bel Cury AA, Derbyshire MTVC, Tabchoury CPM. Biochemical composition and cariogenicity of dental plaque formed in the presence of sucrose or glucose and fructose. Caries Res 2000;34:491-7.

5. Cury JA, Rebello MAB, Del Bel Cury AA. In situ relationship between sucrose exposure and the composition of dental plaque. Caries Res 1997;31:356-60. 
Tenuta LMA, Lima JEO, Cardoso CL, Tabchoury CPM, Cury JA. Effect of plaque accumulation and salivary factors on enamel demineralization and plaque composition in situ. Pesqui Odontol Bras 2003;17(4):326-31.

6. Featherstone JDB, Mellberg JR. Relative rates of progress of artificial carious lesions in bovine, ovine and human enamel. Caries Res 1981;15:109-14.

7. Geddes DAM, Cooke JA, Edgar WM, Jenkins GN. The effect of frequent sucrose mouth rinsing on the induction in vivo of caries-like changes in human dental enamel. Arch Oral Biol 1978;23:663-5.

8. Gold OG, Jordan HV, van Houte J. A selective medium for Streptococcus mutans. Arch Oral Biol 1973;18:1357-64.

9. Klock B, Krasse B. A comparison between different methods for prediction of caries activity. Scand J Dent Res 1979;87:129-39.

10. Köhler B, Petterson BM, Bratthall D. Streptococcus mutans in plaque and saliva and the development of caries. Scand J Dent Res 1981;89:19-25.

11. Mattos-Graner RO, Smith DJ, King WF, Mayer MP. Water insoluble glucan synthesis by mutans streptococcal strains correlates with caries incidence in 12- to 30-month-old children. J Dent Res 2000;79:1371-7.

12. Mikkelsen L, Poulsen S. Microbiological studies on plaque in relation to development of dental caries in man. Caries Res 1976;10:178-88.

13. Miles AA, Misra SS, Irwin JO. The estimation of the bactericidal power of the blood. J Hyg 1938;38:732-49.

14. Minah GE, Lovekin GB, Finney JP. Sucrose-induced ecological response of experimental dental plaques from caries-free and caries-susceptible human volunteers. Infect Immun 1981;34:662-75.

15. Nobre dos Santos M, Melo dos Santos L, Francisco SB, Cury JA. Relationship among dental plaque composition, daily sugar exposure and caries in the primary dentition. Caries Res 2002;36:347-52.

16. Ostrom CA, Koulourides T, Hickman F, McGhee JR. Microbial characterization of an experimental cariogenic plaque in man. J Dent Res 1977;56:550-8.

17. Sullivan A, Borgström MK, Granath L, Nilsson G. Number of mutans streptococci or lactobacilli in a total dental plaque sample does not explain the variation in caries better than the numbers in stimulated whole saliva. Community Dent Oral Epidemiol 1996;24:159-63.

18. Tenovuo J. Salivary parameters of relevance for assessing caries activity in individuals and populations. Community Dent Oral Epidemiol 1997;25:82-6.

19. Tukia-Kulmala H, Tenovuo J. Intra- and inter-individual variation in salivary flow rate, buffer effect, lactobacilli, and mutans streptococci among 11- and 12-year-old schoolchildren. Acta Odontol Scand 1993;51:31-7.

20. van Houte J, Russo J, Prostak KS. Increased pH-lowering ability of Streptococcus mutans cell masses associated with extracellular glucan-rich matrix material and the mechanisms involved. J Dent Res 1989;68:451-9.

21. van Ruyven FOJ, Lingström P, van Houte J, Kent R. Relationship among mutans streptococci, "low-pH" bacteria, and iodophilic polysaccharide producing bacteria in dental plaque and early enamel caries in humans. J Dent Res 2000;79:778-84.

22. von der Fehr FR, Löe H, Theilade E. Experimental caries in man. Caries Res 1970;4:131-48.

23. Zero DT. In situ caries models. Adv Dent Res 1995; 9:214-30.

Recebido para publicação em 25/03/03 Enviado para reformulação em 25/06/03 Aceito para publicação em 14/08/03 